(2) OPEN ACCESS

\title{
Lenalidomide-induced focal myocarditis mimicking acute ST segment elevation myocardial infarction
}

\author{
Yiu-Hei Tse, ${ }^{1}$ Wing-Sze Chan, ${ }^{2}$ Chor-Sang Chim, ${ }^{2}$ Hung Fat Tse $\left[{ }^{2}\right.$
}

'LKS Faculty of Medicine, University of Hong Kong, Hong Kong, China

${ }^{2}$ Medicine, University of Hong Kong, Hong Kong, China

\section{Correspondence to}

Dr Hung Fat Tse, Medicine, The University of Hong Kong, Hong Kong, China;

hftse@hkucc.hku.hk

Received 7 October 2020 Revised 23 October 2020 Accepted 29 October 2020
D) Check for updates

(c) Author(s) (or their employer(s)) 2020. Re-use permitted under CC BY-NC. No commercial re-use. See rights and permissions. Published by BMJ.

To cite: Tse Y-H, Chan W-S, Chim C-S, et al. Postgrad Med J Epub ahead of print: [please include Day Month Year]. doi:10.1136/ postgradmedj-2020-139107
An 86-year-old woman with a history of hypertension and diabetes presented with left-sided chest pain and dyspnoea 2 weeks after her treatment for diffuse large B-cell lymphoma. She was treated with a chemo-free regimen with intravenous rituximab $375 \mathrm{mg} / \mathrm{m}^{2}$, and oral lenalidomide $15 \mathrm{mg} 5$ days/ week for 3 weeks before admission. ${ }^{1}$ On admission, her 12-lead ECG showed sinus bradycardia and $1 \mathrm{~mm}$ ST segment elevation over lead III and aVF (figure 1). Bedside echocardiogram showed left ventricular (LV) ejection fraction (LVEF) of $50 \%$ with inferior wall hypokinesia. Her first serum troponin $\mathrm{T}$ (TnT) level was markedly elevated to $4239 \mathrm{ng} / \mathrm{L}$ (figure 1). Therefore, she was initially diagnosed to have inferolateral ST segment elevated myocardial infarction (MI). Urgent cardiac catheterisation was performed which showed normal coronary arteries but marked hypokinesia at the inferior wall on left ventriculogram. Complete blood count did not reveal eosinophilia, and all viral and immune markers workup were negative. A tentative diagnosis of Takotsubo cardiomyopathy was made.

Lenalidomide was withheld on admission and then resume on next day after cardiac catheterisation. However, she developed chest pain after resuming two doses of lenalidomide. Her serum TnT level raised again 3 hours later to a peak of $9611 \mathrm{ng} / \mathrm{L}$ (figure 1). ECG showed persistent ST elevation of lead III and aVF. Lenalidomide was immediately withdrawn, and her TnT levels eventually decreased to $593 \mathrm{ng} / \mathrm{L}$ (figure 1). She declined an endomyocardial biopsy. Cardiac MRI performed 1 week after admission revealed global hypokinesia with LVEF 50\% without any delayed hyper-enhancement, and diffuse elevated T1 value (1267-1308 mc) over the myocardium, suggestive of diffuse fibrosis or post-chemotherapy effect (figure 1). Her cardiac status was stabilised and discharged with oral metoprolol and ramipril.

She presented again 2 weeks later with acute heart failure and pulmonary oedema requiring intravenous dopamine and furosemide infusion for stabilisation. Repeated echocardiogram showed globally dilated LV with diffuse hypokinesia and LVEF 25\%. Her serum TnT level was $104 \mathrm{ng} / \mathrm{L}$, but $\mathrm{N}$-terminal pro-hormone brain natriuretic peptide was markedly elevated to $12430 \mathrm{pg} / \mathrm{mL}$. Her oral medications were adjusted and was discharged with metoprolol, sacubitril/valsartan, spironolactone and furosemide. She was seen in clinic 4 weeks later with improvement in symptoms and repeated

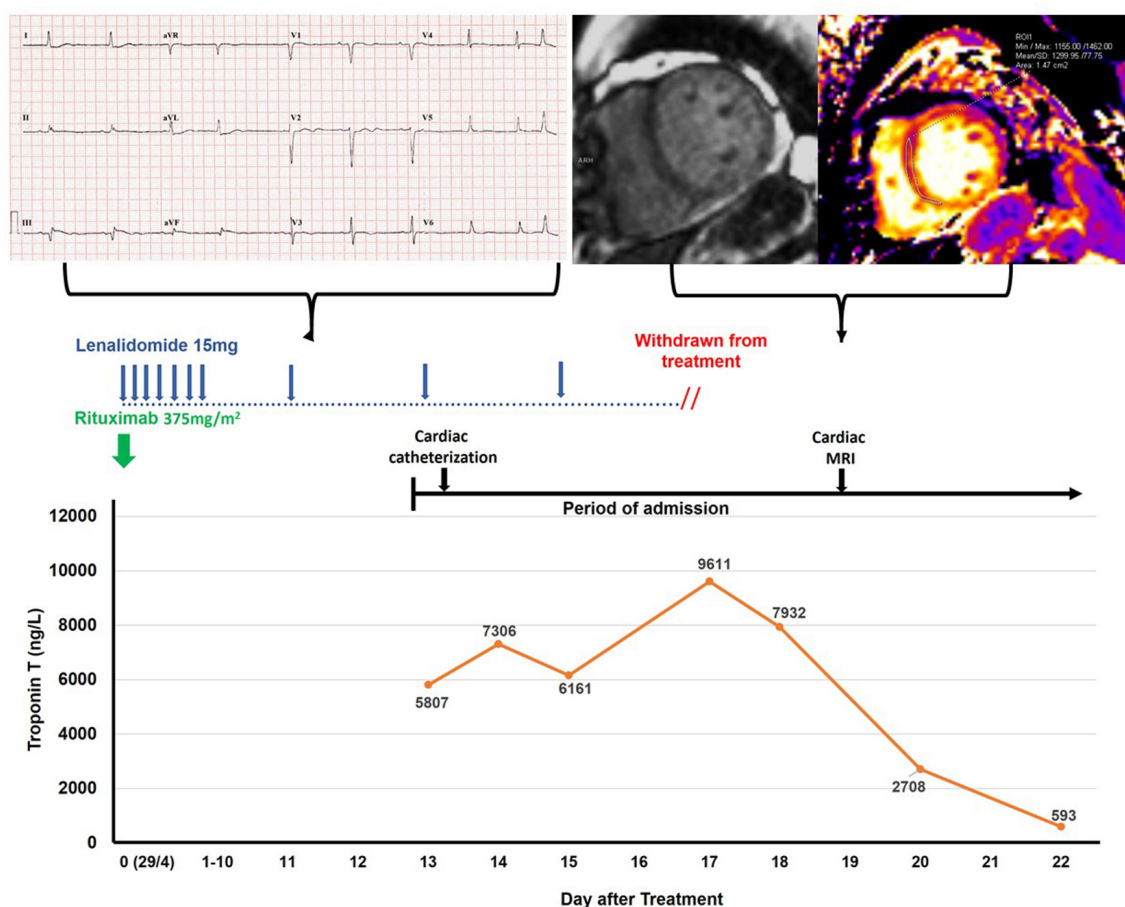

Figure 1 Key clinical events are presented in chronological order outlining timing of therapy with rituximab and lenalidomide, and development of cardiac toxicity. MRI=cardiac MRI. 
echocardiogram showed LVEF 55\% without any regional LV wall hypokinesia.

\section{DISCUSSION}

Two cases of suspected hypersensitivity myocarditis related to lenalidomide ${ }^{23}$ were reported but both lacked a well-established causal relationship. In this patient, the diagnosis of focal myocarditis was made after exclusion of MI due to obstructive coronary artery diseases. Lenalidomide was determined to be the culprit as withdrawal and re-challenging of it led to a fall and rise of TnT levels, respectively, associated with recurring chest pain. While we did not perform endomyocardial biopsy, cardiac MRI showed features suggesting drug-induced myocardial injuries. Other drugs have been linked to hypersensitivity myocarditis, ${ }^{4}$ but rarely can it be presented as focal myocarditis mimicking acute MI similar to our case. ${ }^{5}$ Based on our observation, we encourage clinicians should be aware of the potential of hypersensitivity myocarditis mimicking acute $\mathrm{MI}$ in patients treated with lenalidomide, and should be avoided in its future use in the same patient.

Contributors All the authors have significant contribution to the preparation of the case report. Y-HT and HFT reviewed and wrote the case report. W-SC performed and analysed the cardiac MRI. C-SC and HFT managed the patient.
Funding The authors have not declared a specific grant for this research from any funding agency in the public, commercial or not-for-profit sectors.

Competing interests None declared.

Patient consent for publication Parental/guardian consent obtained.

Provenance and peer review Not commissioned; internally peer reviewed.

Open access This is an open access article distributed in accordance with the Creative Commons Attribution Non Commercial (CC BY-NC 4.0) license, which permits others to distribute, remix, adapt, build upon this work non-commercially, and license their derivative works on different terms, provided the original work is properly cited, appropriate credit is given, any changes made indicated, and the use is non-commercial. See: http://creativecommons.org/licenses/by-nc/4.0/.

\section{ORCID iD}

Hung Fat Tse http://orcid.org/0000-0002-9578-7808

\section{REFERENCES}

1 Wang M, Fowler N, Wagner-Bartak N, et al. Oral lenalidomide with rituximab in relapsed or refractory diffuse large cell, follicular and transformed lymphoma: a phase II clinical trial. Leukemia 2013;27:1902-9.

2 Carver JR, Nasta S, Chong EA, et al. Myocarditis during lenalidomide therapy. Ann Pharmacother 2010:44:1840-3.

3 Sanchez-Petitto G, Hardy N, Burke A, et al. Eosinophilic myocarditis in a patient with multiple myeloma. Clin Lymphoma Myeloma Leuk 2020;20:e392-4.

4 Kuchynka P, Palecek T, Masek M, et al. Current diagnostic and therapeutic aspects of eosinophilic myocarditis. Biomed Res Int 2016;2016:1-6.

5 Li H, Dai Z, Wang B, et al. A case report of eosinophilic myocarditis and a review of the relevant literature. BMC Cardiovasc Disord 2015;15:15. 